\title{
“ARCHIVE OF KHIVA KHANS" AS AN IMPORTANT SOURCE
}

\author{
Aziza Abdukhalilova \\ Scientific researcher, Uzbekistan
}

ABSTRACT: This article explores the role of the archives of Khiva khans in the study of socioeconomic life of the khanate in the XIX-XX centuries, the tax system. Detailed information on the history of the study of the archive and the tax practice of the Bell period was provided.

KEYWORDS: Khiva khans archive, tax accounts, solgut, zakat, count book, A.Kun, P.P. Ivanov, K.Ubaydullaev, judge, escape, clean.

\section{INTRODUCTION}

Today, in our modern historiography, the study of socio-economic aspects of society, the objective coverage of historical facts and the introduction of new historical sources into scientific consumption are topical issues. The adoption of the resolution "On measures to further improve the system of preservation, study and promotion of ancient written sources" highlights the role of archival documents in the study of our history on the basis of primary written sources.

The archive of Khiva khans in the archives of the National Archives of the Republic of Uzbekistan in the Eastern languages serves as an important source in the study of the socioeconomic life of the khanate in the XIX - XX centuries, including the history of the tax system. The growth of commodity-money relations, the strengthening of the khan's power and the centralization of economic reforms as a result of changes in the tax system, the expansion of bureaucracy and reporting, the need for long-term storage of books on government expenditures and taxpayer lists created the Khiva khans' archives.

This archive is a collection of state documents kept by high-ranking officials of the Khiva khanate, the devanbegi, koshbegi and mehtar. Documents on tax collections in the archives of the Khiva khans date back to the period of the Kungrad dynasty, the first of which dates back to 
$1237 / 1824$, the last to $1872-1873$. With a volume of more than eleven thousand, the fund contains 665 documents, mainly in Turkish and Persian ${ }^{1}$.

\section{THE MAIN FINDINGS AND RESULTS}

The archive was confiscated after the Khiva Khanate was occupied by the Russian army in 1873 and taken to Russia for investigation. After that, the history of the archive will remain unknown for a long time. The first information about the archives of the Khiva khans became known through the articles of the orientalist A.Kun, one of the participants of the 1873 military campaign. In one of A. Kun's reports, he writes about the archive: "When the khan's palace was confiscated, documents were collected along with manuscripts. These documents include two groups: the first group includes books on the khanate's income and expenses, as well as a number of waqf and property documents, and the second group includes letters and diplomatic correspondence. The books include tax records, solgut, zakat books, and Matmurad devonbegi's reports on the khan's expenses. In addition, the documents include petitions sent to the khan by Khiva residents living in Bukhara, Razali, Istanbul and other places engaged in trade, written petitions for the settlement of disputes, petitions for a career, and so on.

In 1882, A.L.Kun handed over a part of the archives of Khiva khans to the People's Library. However, this is not the full text of the archive, and the rest of it is transferred to the Asian Museum of the Academy of Sciences after the death of A. Kuhn in 1888. By 1936, PP Ivanov was able to find the notebooks of the Khiva khans in the Manuscripts Department of the ME Saltikov-Shchedrin State Library in Leningrad. Thanks to this discovery, scholars have a valuable, primary source that provides a wealth of information on the history of Khiva and the history of the Central Asian khanates of the last century. The service of PP Ivanov, who found the archive, was to systematize the materials found by scientists. In his work, he summarized the contents of 137 documents in notebooks ${ }^{2}$.

In 1962 the archive of Khiva khans was brought to Tashkent from Russia. Cataloged by Ubaydullaev according to the content of the documents. Currently, the National Archive of Uzbekistan is in the 2 nd list of the $1-125$ fund.

The archival documents of the Khiva khans are primarily records related to tax collection, mainly land tax and zakat collection. The archive, which shows the amount and when

\footnotetext{
${ }^{1}$ Ўз МА.И-125, 2-рўйхат Хива хонлиги архиви хужжатлари фонди.

${ }^{2}$ Иванов П. Архив хивинских ханов ХІХ в исследование и описание документов с историческим введением. Ленинград.1940.С.6
} 
the tax was collected, is the main part of the materials. Some documents contain information on how the money raised was spent.

In addition to the above-mentioned tax records, the archive also contains a set of labels, such tarhan labels, which provide for full or partial exemption from taxes, are important in that they partially reflect tax issues. The periodic boundary of the documents in the collection consists of tarkhan labels, which provide for tax exemptions for 1728-1917, and labels indicating that the land has become private property (labeled property).

Also, the documents of the archives of the Khiva khans contain lists of people sent to work, such as begar, qazu and kachu (cleaning of canals, strengthening dams, construction and repair of roads). The studied documents also mention the issue of fulfillment or release of labor obligations of the population in the section of mosques, and the terms kazu, kachu, biqozu, biqochu, taza are encountered by taxpayers.

Another major tax issue in the khanate, defined by Sharia, was reflected in the archives of the Khiva khans.

When studying the tax system in the Khiva khanate, the documents in the archives of the Khiva khanate serve as an important source. We will have detailed information about the tax system of the period of calls, the existing types of taxes, tax practice, officials in charge of tax collection, the order of paperwork, (on the example of counting books). The archival documents contain special instructions for tax collectors on the levying of taxes on private lands (special and labeled property), and depending on the amount of land, one, two and three gold coins were obtained from the lands of alo, adno and avsot. It was noted that the newly developed lands were privileged and that one gold was to be taken from such lands for every five tanobs. This document served as a program for tax collectors.

In the study of the tax system of the Khiva khanate, we can also see the tax administration and tax practice in the example of the census books of the high officials of the khanate, the devonbegi and the mehtar aga. They were sent to the khan, along with tax records in the ledgers, writing reports on the results of tax practice. The persons responsible for keeping these notebooks have been identified.

Bayani, a historian of the palace who kept the archives of the Khiva khans, mentions that they were preserved in a very careful manner in a special building, under the supervision of separated people, along with the treasure in the palace. 
Published: July 12, 2021 | Pages: 19-22

From the above we can say that archival documents serve as the main source for the researcher in the study of the history of the Khiva khanate in the late XIX - early XX centuries. Indeed, the effective use of primary sources in the creation of an objective and truthful history increases the scientific significance of the work. In studying the tax system of the Kungrad period in the Khiva khanate, it is these documents that not only give us a lot of unknown information, but also help to form a complete picture of the economic life of the khanate.

\section{REFERENCES}

1. Ўзбекистон Республикаси Президентининг 2017 йил 24 майдаги “Қадимий ёзма манбаларни сақлаш, тадқиқ ва тарғиб қилиш тизимини янада такомиллаштириш чоратадбирлари тўғрисида"ги 2995-сонли қарори

2. ЎзР.МА. И-125, 2-рўйхат Хива хонлиги архиви хужжатлари фонди. 382,383,384,419,422,423,425,430,458, 432,441,531-йиғма жилдлар.

3. Баёний. Шажараи Хоразмшохий.Қўлёзма манбалар асосида нашрга тайёрловчи Иқболой Адизова. -Т.1991.

4. Йўлдошев М.Й. Хива хонлигида феодал ер эгалиги ва давлат тузилиши. -Т.1959.Б.23

5. Иванов П. Архив хивинских ханов XIX в исследование и описание документов с историческим введением. -Ленинград.1940.С.6

6. Кун А. Порядок взимания податей в Хивинском ханстве//Туркестанские ведомости. 1873. - №33.C.130-131

7. Кун А. Заметки о подятях в Хивинском ханстве”//Туркестанские ведомости. 1873. №32.C.125-127 